\title{
PENGARUH TERAPI AKUPRESUR TERHADAP PENINGKATAN PRODUKSI ASI PADA IBU POST PARTUM DI PKU MUHAMADIYAH BANTUL
}

\author{
Anita Liliana $^{1}$, Melania Wahyuningsih ${ }^{2}$ \\ ${ }^{1,2}$ Program Studi Keperawatan Program Sarjana Universitas Respati Yogyakarta \\ Email:melania@respati.ac.id
}

\begin{abstract}
Abstrak
Kecukupan produksi ASI pada bayi baru lahir akan mempengaruhi keberhasilan dalam memberikan ASI eksklusif. Belum semua ibu postpartum mampu untuk meningkatkan produksi ASI pada masa postpartum. Akupresur pada titik meridian merupakansalah satu cara untuk meningkatkan produksi ASI pada ibu postpartum. Penelitian ini bertujuan untuk mengetahui pengauh terapi akupresur terhadap peningkatan produksi ASI pada ibu postpartum di PKU Muhamadiyah Bantul. Penelitian ini menggunakan jenis kuantitatif dengan desain penelitian eksperimen semu atau quasi experiment dengan jenis Pre-test and Post-test nonequivalent control group. Jumlah responden masing masing kelompok berjumlah 17 orang. Perlakuan yang diberikan adalah akupresur pada titik titik meridian selama 5 menit pada hari ke 2 dan 3. Kecukupan ASI dinilai sebelum perlakuan dan pada hari ke 4 postpartum. Data dianalisa dengan analisa Mc Nemar. Hasil penelitian menunjukkan ada perbedaan yang significant produksi ASI sebelum dan sesudah akupresur $p$ value 0,000 ( $p$ value $<0,05$ ). Ada perbedaan produksi produksi ASI yang significant pada kelompok kontrol sebelum dan sesudah diberikan leaflet teknik menyusui $\mathrm{p}$ value 0,001 ( $\mathrm{p}$ value $<0,05$ ). Kesimpulan: Tidak ada perbedaan yang significant produksi ASI sesudah diberikan akupresur dan dan sesudah diberikan leaflet tentang teknik menyusui di PKU Muhamadiyah Bantul p value 0.100 $(\mathrm{p}$ value $>0,05)$
\end{abstract}

Kata kunci: akupresur, produksi ASI, postpartum

\begin{abstract}
Adequacy of milk production in the newborns will affect the success of exclusive breastfeeding. Not all postpartum mothers are able to increase milk production in the postpartum period. Acupressure at the meridian points is one way to increase milk production in postpartum mothers. This study aims to determine the effect of acupressure therapy on increasing breast milk production in postpartum mothers at PKU Muhamadiyah Bantul. This study was a quantitative study a quasi-experimental research design with pre-test and post-test nonequivalent control group. The number of respondents in each group was 17 people. The treatment given was acupressure at the meridian points for 5 minutes on days 2 and 3 of poatpartum. Breastfeeding adequacy was assessed before treatment and on day 4 postpartum. Data were analyzed by Mc Nemar analysis. The results showed that there was a significant difference in breast milk production before and after acupressure with $\mathrm{p}$ value of 0.000 ( $p$ value $<0.05$ ). There was a significant difference in breast milk production in the control group before and after being given the breastfeeding technique leaflet $p$ value 0.001 ( $p$ value $<0.05$ ). Conclusion: There is no significant difference in breast milk production after being given acupressure and after being given leaflets about breastfeeding techniques at PKU Muhamadiyah Bantul $\mathrm{p}$ value 0.100 ( $\mathrm{p}$ value $>0.05$ ).
\end{abstract}

Keywords: acupressure, breast milk production, postpartum 


\section{LATAR BELAKANG}

Menyusui merupakan suatu aktivitas yang bisa mendatangkan kebahagiaan tersendiri bagi ibu. Air susu ibu (ASI) bermanfaat untuk menjaga ketahanan tubuh bayi karena mengandung zat anti infeksi, gizi yang unik, protein utama berupa lactabumin yang mudah dicerna, kandungan vitamin dan mineral yang banyak (Delima dkk, 2016). Sampai saat ini, pemberian ASI di Indonesia masih sangat rendah. Data Profil Kesehatan Indonesia (2018) menunjukan bahwa bayi yang mendapatkan ASI ekslusif sampai 6 bulan sebanyak 35,73\% (Kemenkes, 2018). Sedangkan berdasarkan hasil Profil Kesehatan Provinsi Di Yogyakarta Tahun 2017 bayi yang mendapatkan ASI ekslusif di Yogyakarta sebanyak $74,90 \%$ dan bayi yang mendapat ASI ekslusif di Kabupaten Sleman yaitu sebanyak 82,62\% (Dinkes DIY, 2017). Ketidakcukupan ASI adalah alasan utama ibu untuk menghentikan pemberian ASI, karena ibu merasa ASI nya tidak cukup untuk memenuhi kebutuhan bayi dan mendukung kenaikan berat badan bayi (Rahayu \& Yunarsih, 2018).

Kecukupan produksi ASI pada bayi dipengaruhi oleh kelancaran dan frekuensi menyusui, namun masih banyak ibu yang masih kurang informasi tentang frekuensi dan cara menyusui yang benar (Lismayarsah, 2013). Ketidakcukupan ASI pada bayi akan mengakibatkan masalah sindrom ASI kurang yang menyebabkan bayi mengalami ketidakpuasan setelah menyusu, bayi sering menangis atau rewel, tinja bayi keras dan payudara tidak terasa membesar (Marmi, 2015). Kegagalan bayi untuk menyusu merupakan salah satu faktor yang menyebabkan produksi ASI lebih dari 3 hari, frekuensi menyusui berhubungan dengan rangsangan isapan pada payudara dengan produksi oksitosin dan prolaktin untuk memproduksi air susu (Angriani \& Sudaryati, 2018). Sehingga tidak mengherankan apabila sebanyak $35 \%$ ibu memberikan makanan tambahan pada bayi sebelum usia enam bulan karena adanya persepsi ketidakcukupan ASI (Prastiwi dkk, 2018).

Hormon prolaktin dan oksitosin sangat berperan dalam kecukupan produksi ASI (Rahayu dkk, 2015), ada dua reflek pada ibu yang sangat penting dalam proses laktasi yaitu reflek prolaktin dan reflek aliran (let down refle (Walyani \& Purwoastuti, 2017) . Jika oksitosin sedikit, maka let down reflex akan terhambat sehingga ASI tidak bisa keluar dari payudara (Asih \& Risneni, 2016). Salah satu cara membangkitkan let down reflex yaitu dengan melakukan terapi Akupresur, Akupresur berhubungan dengan sistem meridian dan energi vital/chi sie (Setyowati, 2018).

Akupresur merupakan penekanan menggunakan jari yang dapat memberikan stimulasi sensori stomatic melalui jalur aferen sehingga mempengaruhi aliran bioenergy (Qi) yang mengalir dalam satu meridian atau aliran, rangsangan pada titik meridian akan memberikan fungsi kerja yang maksimal yang berhubungan dengan organ tersebut. Rangsangan tersebut dapat melewati jalur saraf, somatoviceral, garis meridian dan reaksi lokal. Stimulasi sensorik yang dihasilkan akupresur akan merangsang hipofisis posteririor dan pituitary yang akan mempengaruhi perbaikan kerja fungsi dari hormon yang akan meningkatkan produksi ASI (Rahayu dkk, 2015). pelepasan hormon oksitosin akan merangsang terjadinya let down reflex sehingga terjadi proses ejeksi ASI dari alveoli dan ductus lactiferious yang secara otomatis ASI pun keluar ( Dewi dkk, 2018).

Menurut hasil penelitian Djanah \& Muslihatun, (2017) yang berjudul Akupresur terhadap produksi ASI pada ibu postpartum di klinik Mujahidah Bantul, menjelaskan bahwa ada pengaruh akupresur terhadap produksi ASI padas ibu postpartum, hasil penelitian menunjukan setelah dilakukan 
akupresur, rata-rata berat bayi pada umur dua minggu adalah 3318 gram dan pada umur empat minggu ratarata berat bayi adalah 3668 gram. Hal ini juga ditunjukan oleh hasil penelitian Cholifah dkk, (2014) dengan judul Akupresur pada ibu menyusui meningkatkan kecukupan ASI asupan ASI bayi di Kecamatan Mungkid Menjelaskan bahwa kecukupan ASI bayi pada kelompok intervensi meningkat dari $35 \%$ menjadi $85 \%$. Hal ini membuktikan bahwa Akupresur dapat meningkatkan kecukupan ASI.

Hasil studi pendahuluan yang dilakukan oleh peneliti di PKU Muhamadiyah Bantul pada bulan Januari 2020. diketahui jumlah ibu nifas yang melahrikan secara normal selama 3 bulan teraakhir sebanyak 153 dan rata rata perbulannya mencapai 51 ibu nifas. diperoleh data hasil wawancara kepada enam responden didapatkan beberapa hambatan yang dialami responden untuk mencukupi kebutuhan ASI bayinya diantaranya dua responden bayinya rewel, empat responden mengatakan ASI nya belum keluar, enam responden payudaranya tidak terasa penuh sebelum menyusui, satu responden putting lecet, satu responden bayinya belum BAB, dua responden bayinya belum BAK, enam responden mengatakan belum pernah melakukan atau diberikan terapi akupresur untuk melancarkan atau meningkatkan produksi ASInya. Berdasarkan latar belakang diatas peneliti tertarik untuk melakukan penelitian dengan judul "Pengaruh Terapi Akupresur terhadap Peningkatan produksi ASI pada Ibu Post Partum”.

\section{METODE PENELITIAN}

Penelitian ini menggunakan jenis kuantitatif dengan desain penelitian eksperimen semu atau quasi experiment dengan jenis Pre-test and Post-test nonequivalent control group (Dharma, 2013). Penelitian quasi experiment dengan jenis Pre-test and Post-test nonequivalent control group adalah penelitian yang menguji coba suatu intervensi pada kelompok subyek dengan kelompok kontrol namun tidak dilakukan randomisasi untuk memasukkan subyek kedalam kelompok perlakuan dan kelompok kontrol. Pada jenis penelitian Pre-test and Post-test nonequivalent control group sebelum diberikan perlakuan, responden kelompok perlakuan $\left(\mathrm{R}_{1}\right)$ dan responden kelompok kontrol $\left(\mathrm{R}_{2}\right)$ diberikan test awal atau pre test untuk mengukur kondisi awal. Setelah dilakukan pretes pada kedua kelompok maka selanjutnya diberikan perlakuan kepada kelompok perlakuan (X), setelah selesai diberi perlakuan kelompok perlakuan $\left(\mathrm{O}_{1}\right)$ dan kelompok kontrol $\left(\mathrm{O}_{2}\right)$ dilakukan tes lagi atau postes. Pada penelitian ini kelompok perlakuan diberikan akupresur pada titik meridian untuk melancarkan ASI selama 2 hari pada hari ke 2 dan ke 3 postartum. Akupresur pada titik meridian diberikan selama 5 menit. Pada kelompok kontrol diberikan leaflet tentang teknik menyusui yang benar pada hari ke 2 postpartum . Penilaian produksi ASI dilakukan sebelum perlakuan akupresur pada hari ke 2 dan pada hari ke 4 . 


\section{HASIL DAN PEMBAHASAN}

Tabel 1 Distribusi Frekuensi Responden Berdasarkan Usia, Paritas, dan Usia Gestasi, (n : 34)

\begin{tabular}{lllll}
\hline \multirow{2}{*}{ Karakteristik Responden } & Perlakuan & \multicolumn{3}{c}{ Kontrol } \\
\cline { 2 - 5 } & Frekuensi & $(\%)$ & Frekuensi & $(\%)$ \\
\hline Usia (Tahun) : & 17 & 100 & 16 & 94,1 \\
$20-35$ & 0 & 0 & 1 & 5,9 \\
$36-45$ & & & & \\
& 8 & 47,1 & 8 & 47,1 \\
\hline Paritas & 9 & 52,9 & 9 & 52,9 \\
Primipara & & & & \\
Multipara & 2 & 11,8 & 4 & 31,2 \\
& 15 & 88,2 & 15 & 68,8 \\
\hline $\begin{array}{l}\text { Usia Gestasi } \\
\text { Prematur }\end{array}$ & & & & 100,0 \\
\hline Tterm & 17 & 100,0 & 17 & \\
\hline
\end{tabular}

Berdasarkan tabel 1 menunjukkan bahwa sebagian besar responden baik kelompok perlakuaan dan kelompok kontrol berusia $20-35$ tahun, paritas multipara dan melahirkan pada usia kehamilan yang aterm. Berdasarkan data karakteristik diatas dapat disimpulkan bahwa ibu postpartum melahirkan pada usia reproduksi sehat, dan hanya lorang ibu pada kelompok kontrol yang melahirkan pada usia 42 tahun. Semua ibu melahiran dengan paritas primipara dan multipara yang berarti jumlah anak yang dilahirkan oleh ibu postpartum stu sampai 3. Usia kehamilan saat bayi dilahirkan sebagian besar usia aterm. Bayi yang lahir pada usia kehamilan aterm memiliki berat badan yang normal.

Tabel 2 Distribusi Tingkat Kecukupan Produksi ASI pada Kelompok Perlakuan dan Kontrol. (n : 34)

\begin{tabular}{lcccc}
\hline \multicolumn{1}{c}{ Produksi ASI } & Sebelum & \multicolumn{3}{c}{ Sesudah } \\
& Frekuensi & $(\%)$ & $\begin{array}{c}\text { Frekuens } \\
\text { i }\end{array}$ & $(\%)$ \\
\hline Perlakuan & & & & \\
Cukup & 0 & 0 & 13 & 76,5 \\
Tidak Cukup & 17 & 100,0 & 4 & 23,5 \\
\hline Kontrol & 1 & & & \\
Cukup & 16 & 5,9 & 12 & 70,5 \\
Tidak Cukup & 17 & 94.1 & 5 & 29,5 \\
\hline Total & & 100,0 & 17 & 100,0 \\
\hline
\end{tabular}

Berdasarkan tabel 2 menunjukkan bahwa kecukupan produksi ASI pada kelompok intervensi sebelum dilakukan akupresur dalam kategori tidak cukup (100\%). Setelah dilakukan akupresur produksi ASI sebagian besar dalam kategori cukup (76,5\%). Pada kelompok kotrol sebelum diberikan leaflet tentang teknik menyusui sebagian besar ibu memiliki kecukupan ASI dalam kategori 
tidak cukup (94,1\%), setelah diberikan leaflet teknik menyusui sebagian besar dalam kategori cukup ( 70,5 \%).

Pada kelompok perlakuan pijat akupresur dilakukan dua kali pada hari ke dua dan hari ke tiga postpartum. ASI pada ibu postpartum keluar pada hari kedua atau ketiga. Produksi ASI atau Kecukupan produksi ASI adalah kecukupan bayi dalam mendapatkan ASI dilihat dari Berat Badan Bayi, frekuensi $\mathrm{BAK}$, pola $\mathrm{BAB}$, perilaku bayi dan kondisi payudara ibu. Pada hari kedua sebelum diberikan pijar akupresur produksi ASI semua ibu postpartum dalam kategori tidak cukup (100\%). Akupresur dilakukan dua hari berturut pada pada hari kedua dan hari ketiga. Akupresur dilakukan pada titik pemijatan dan stimulasi pada titik akupoin yang bermanfaat memberikan rasanyaman pada ibu. Titik-titik akupresur yaitu: Meridian REN CV 17 meridian lambung ST 18, ST 15, ST 16, ST 36 meridian limpa SP 18, meridian usus kecil SI 1, SI 2 meridian usus besar LI 4, meridian kandung empedu GB 21, pemijatan dilakukan 2040 detik selama 5 menit pada hai ke 2 dan ke 3 postpartum. Produksi ASI dievaluasi sebelum perlakuan dan pada hari ke 4 postpartum.

Akupresur merupakan penekanan menggunakan jari yang dapat memberikan stimulasi sensori stomatic melalui jalur aferen sehingga merangsang hipofisis posteriror untuk melepaskan hormone oksitosin yang akan merangsang terjadinya let down reflex sehingga terjadi proses ejeksi ASI dari alveoli dan ductus lactiferious yang secara otomatis ASI pun keluar (Dewi dkk, 2018). Akupresur menggunakan metode perangsangan pada titik akupuntur sehingga dapat meningkatkan oksitosin yang diperlukan tubuh untuk merangsang pengeluaran ASI (Susilawati \& Halim, 2018).

Menurut hasil penelitian Djanah \& Muslihatun, (2017) yang berjudul Akupresur terhadap produksi ASI pada ibu postpartum di klinik Mujahidah Bantul, hasil penelitian menunjukan setelah dilakukan akupresur, rata-rata berat bayi pada umur dua minggu adalah 3318 gram dan pada umur empat minggu ratarata berat bayi adalah 3668 gram. Akupresur dapat mempengaruhi peningkatan berat badan bayi.

Pada kelompok kontrol tidak diberikan diberikan leaflet dan pendidikan kesehatan tentang cara menyusui yang baik. Produksi ASI sebelum diberikan leaflet dan pendidikan kesehatan mayoritas dalam kategori tidak cukup 94,1 $\%$, dan yang dalam kategori cukup hanya 5,9 \%. Pada kelompok kontrol meskipun tidak diberikan perlakuan akupresur diberikan pendidikan kesehatan tentang teknik menyusui yang baik sehingga ibu postpartum mendapatkan informasi teknik menyusui yang baik pada bayinya. Menurutu Marmi, (2015) tujuan menyusui yang benar adalah untuk merangsang kecukupan produksi ASI serta memperkuat reflex menghisap bayi. Informasi tentang teknik menyusui tersebut diterapkan oleh ibu poatpartum dalam menyusui bayinya, sehingga produksi ASI setelah diberikan leaflet dan pendidikan kesehatan mejadi kategori cukup 70,5\% dan tidak cukup 29,5\%. 
Tabel 3 Perbedaan Produksi ASI Sebelum dan Sesudah Diberikan Intervensi Akupresur pada Kelompok Intervensi, (n : 17)

\begin{tabular}{lccccc}
\hline \multicolumn{1}{c}{ Produksi ASI } & Sebelum & & Sesudah & & p value \\
\hline & Frekuensi & $\mathbf{( \% )}$ & Frekuensi & $\mathbf{( \% )}$ & \\
\hline Perlakuan & & & & & \\
- Cukup & 0 & 0 & 13 & 76,5 & 0,000 \\
- Tidak Cukup & 17 & 100,0 & 4 & 23,5 & \\
\hline Total & 17 & 100,0 & 17 & 100,0 & \\
\hline
\end{tabular}

Produksi ASI kelompok perlakuan sebelum diberikan akupresur semuanya dalam kategori tidak cukup (100\%), sesudah diberikan perlakuan akupresur produksi ASI dalam kategori cukup 76,5\% dan tidak cukup 23,5\%. Analisa Mc Nemar pada tabel 3 menunujukkan produksi ASI sebelum dan sesudah diberikan intervensi Akupresur hasil $p$ value 0,000 artinya ada pengaruh akupresur terhadap produksi ASI

Laktogenesis II merupakan awal terjadinya produksi ASI dimulai setelah pengeluaran plasenta dan membranmembran yang mengakibatkan penurunan kadar progesterone, estrogen, HPL dan PIF (kontrol neuro endokrin) secara tiba-tiba. Laktogenesis II dimulai 40-72 jam setelah melahirkan, tetapi para ibu tidak merasakan bahwa air susu keluar sampai 2-3 hari setelah melahirkan (Lawrence \& Lawrence, 2011)

Akupresur adalah teknik pengobatan nonfarmakologi yang berkaitan erat dengan akupuntur, dengan melakukan tekanan pada titik-titik tertentu dalam tubuh (Djanah \& Muslihatun, 2017). Akupresur merupakan satu fisioterapi dengan memberikan pijatan dan stimulasi pada titik-titik tertentu pada tubuh yang berguna untuk mengurangi atau mengobati berbagai jenis penyakit dan nyeri serta mengurangi ketegangan dan kelelahan (Cholifah dkk, 2014). Ibu postpartum yang mengalami kelelahan setelah melahirkan apabila diberikan pemijatan pada titik akupresus akan merasa nyaman, rileks dan tidak tegang sehingga ASI akan banyak keluar dan kebutuhan bayi tercukupi. Akupresur berhubungan dengan sistem meridian dan energi vital/chi sie (Setyowati, 2018).

Cholifah dkk, (2014) dengan judul Akupresur pada ibu menyusui meningkatkan kecukupan ASI asupan ASI bayi di Kecamatan Mungkid Menjelaskan bahwa kecukupan ASI bayi pada kelompok intervensi meningkat dari $35 \%$ menjadi $85 \%$. Hal ini membuktikan bahwa Akupresur dapat meningkatkan kecukupan ASI.

Tabel 4 Perbedaan Produksi ASI Sebelum Dan Sesudah Diberikan Leaflet Tentang Teknik Menyusui Pada Kelompok Kontrol $(\mathrm{N}=17)$

\begin{tabular}{lccccc}
\hline \multicolumn{1}{c}{ Produksi ASI } & Sebelum & \multicolumn{3}{c}{ Sesudah } & P value \\
\hline & Frekuensi & $\mathbf{( \% )}$ & Frekuensi & $\mathbf{( \% )}$ & \\
\hline Kontrol & & & & & \\
- Cukup & 1 & 5,9 & 12 & 70,5 & 0,001 \\
- Tidak Cukup & 16 & 94.1 & 5 & 29,5 & \\
\hline Total & 17 & 100,0 & 17 & 100,0 & \\
\hline
\end{tabular}


Tabel 4 Pada table 4 menunjukkan bahwa perbedaan produksi asi sebelum dan sesudah diberikan leaflet tentang teknik menyusui pada kelompok kontrol pada analisa Mc Nemar p value 0,001 ( < 0,05 ) ada pebedaan yang significant produksi ASI sebelum dan sesudah diberikan leaflet tentang teknik menyusui. Hal ini disebabkan karena meskipun kelompok control tidak diberikan intervensi, mendapatkan leaflet dan penjelasan dari peneliti tentang teknik menyusui. Penjelasan yang diberikan oleh peneliti tersebut dilaksanakan oleh responden. Alasan responden saat diwawancara peneliti saat mengevaluasi produksi ASI pada hari kedua adalah ibu postpartum ingin memberikan ASI yang cukup pada bayinya supaya bayinya sehat. Hali ini dilaksanakan oleh semua responden memberikan ASI sesering mungkin setiap 1-2 jam, sehingga semua responden mengalami peningkatan produksi ASI.
Sewaktu bayi menghisap, ujung saraf peraba yang terdapat pada putting susu terangsang. Rangsangan tersebut oleh serabut afferent dibawa ke hipotelamus didasar otak, lalu memacu hipofisis anterior untuk mengeluarkan hormon prolaktin ke dalam darah. Melalui siklus prolaktin memacu sel kelenjar (alveoli) untuk memproduksi air susu. Jumlah prolactin yang disekresi dan jumlah susu yang diproduksi dan lamanya bayi menghisap (Walyani \& Purwoastuti, 2017).

Rangsangan yang ditimbulkan oleh bayi saat menyusu selain memengaruhi hipofisis anterior mengeluarkan hormon prolaktin juga memengaruhi hipofisis posterior mengeluarkan hormon oksitosin. Dimana setelah oksitosin dilepaskan kedalam darah mengacu otot-otot polos yang mengelilingi alveoli dan duktulus berkonsentrasi sehingga memeras air susu dari alveoli, duktulus dan sinus menuju putting susu. Saat dihisap bayi ASI yang keluar cukup banyak.

Tabel 5 Perbedaan Produksi ASI Sesudah Diberikan Intervensi Akupresur Kelompok Perlakuan Dan Sesudah Diberikan Leaflet Tentang Teknik Menyusui Kelompok Kontrol (N-34)

\begin{tabular}{lccccc}
\hline \multicolumn{1}{c}{ Produksi ASI } & Perlakuan & \multicolumn{3}{c}{ Kontrol } & P value \\
\hline & Frekuensi & $\mathbf{( \% )}$ & Frekuensi & $\mathbf{( \% )}$ & \\
\hline - Cukup & 13 & 76,5 & 12 & 70,5 & 1.000 \\
- Tidak Cukup & $\mathbf{4}$ & 23,5 & 5 & 29,5 & \\
\hline Total & 17 & 100,0 & 17 & 100,0 & \\
\hline
\end{tabular}

Produksi ASI sesudah diberikan perlakuan akupresur dan setelah diberikan leflet teknik menyusui $p$ value 1,000 artinya tidak ada perbedaan yang significant setelah diberikan akupresur dan leaflet teknik menyusui. Hal ini disebabkan karena kelompok perlakuan dan kelompok control mengalami peningkatan produksi ASI.
Pada kelompok perlakuan peningkatan produksi ASI disebabkankan karena perlakuan Akupresur Menurut Setyowati, (2018) akupresur memanfaatkan rangsangan pada titik-titik Akupuntur tubuh pasien, telinga atau kulit kepala untuk mempengaruhi aliran bioenergi tubuh yang disebut dengan qi. Qi mengalir dalam suatu meridian (saluran), jadi inti 
pengobatan akupresur/akupuntur adalah mengembalikan system keseimbangan (homeostasis) tubuh ynag terwujud dengan adanya aliran qi yang teratur dan harmonis dalam meridian sehingga pasien sehat kembali. Dengan menguatnya qi, daya tahan tubuh menjadi baik. Pada ibu postpartum yang mengalami kelelahan akibat persalinan dengan akupresur ini akan menjadi rileks dan nyaman sehingga aliran darah menjadi lancer dan produksi ASI meningkat.

Penelitian ini sesuai dengan penelitian yang dilakukan oleh Cholifah dkk, (2014) dengan judul Akupresur pada ibu menyusui meningkatkan kecukupan ASI asupan ASI bayi di Kecamatan Mungkid Menjelaskan bahwa kecukupan ASI bayi pada kelompok intervensi meningkat dari $35 \%$ menjadi $85 \%$. Hal ini membuktikan bahwa Akupresur dapat meningkatkan kecukupan ASI.

Pada kelompok kontrol meskipun tidak mendapatkan perlakuan produksi ASI meningkat disebabkan adanya keinginan yang kuat dari ibu post partum untuk memenuhi kecukupan ASI pada bayinya sehingga ibu menyusui bayinya sesering mungkin setiap $1-2$ jam. Sebenarnya setelah dihisap bayi, ASI yang tadinya keluar sedikit akan menjadi banyak. Secara alamiah bayi akan mengatur kebutuhannya sendiri. Semakin sering bayi menyusu maka payudara akan memproduksi lebih banyak ASI ( Astuti $\mathrm{dkk}, 2015)$.

\section{KESIMPULAN}

Ada pengaruh pengaruh terapi akupresur terhadap peningkatan produksi ASI pada ibu postpartum di PKU Muhamadiyah Bantul.p value 0,000 . Ada pengaruh pemberian lealet tentang teknik menyusui terhadap peningkatan produksi ASI ibu postpaertum di PKU Muhamadiyah Bantul.p value 0,001 .
Tidak ada perbedaan produksi ASI pada kelompok intervensi yang diberikan akupresur dan kelompok kontrol yang diberikan leaflet teknik menyusui $\mathrm{p}$ value 0.100 .

\section{SARAN}

Bagi RS PKU Muhamadiyan Bantul Dalam memberikan pelayanan terhadap kesehatan ibu di poliklinik KIA dan di ruang nifas bisa memberikan edukasi akupresur untuk meningkatkan produksi ASI. Bagi peneliti selanjutnya bisa melakukan penelitian akupresur untuk mengatasi masalah kesehatan yang lain.

\section{DAFTAR PUSTAKA}

Angriani, R., \& Sudaryati, E. (2018). Hubungan Frekuensi Menyusui Dengan Kelancaran Produksi ASI Ibu Postpartum Di Wilayah kerrja Puskesmas Peusangan Selatan Kabupaten Bireuen Provinsi Aceh Tahun 2017. Jurnal Muara Sains, Teknologi, Kedokteran, Dan Ilmu Kesehatan, 2(1), 299-304.

Asih, Y., \& Risneni. (2016). Buku Ajar Asuhan Kebidanan Nifas Dan Menyusui. Jakarta: Trans Info Media.

Astuti, R. P., \& et al. (2015). Pengaruh Pijat Punggung dan Memerah ASI terhadap Produksi ASI pada Ibu Postpartum dengan Seksio Sesarea Effect of Back Massage and Expressing Breast Milk on the Milk Production of Postpartum Mothers with Caesarean Section. IJEMC, 2(1), 1-8.

Astutik, \& Yuli, R. (2014). Payudara dan Laktasi. Jakarta: Salemba Medika.

Cholifah, S., Er, H. S., \& Mareta, R. (2014). Akupresur Pada Ibu Menyusui 
Meningkatkan Kecukupan Asupan Asi Bayi Di Kecamatan Mungkid Tahun 2014. Jurnal Keperawatan Maternitas, $3(2), 111-117$.

Delima, M., Arni, G. Z., \& Rosya, E. (2016). Pengaruh pijat oksitosin terhadap peningkatan produksi ASI ibu menyusui di Puskesmas Plus Mandiangin. Jurnal Ipteks Terapan, 9(4), 282-293. https://doi.org/10.22216/jit.2015.v9i4.5 71

Dewi, A., Dasuki, D., \& Kartini, F. (2018). Pengaruh Pijat Oksitosin Terhadap Produksi ASI Pada Ibu Pasca Bedah Sesar Di RSUD Kebumen.

Dharma, K. K. (2013). Metodologi Penelitian Keperawatan Panduan Melaksanakan Dan Menerapkan Hasil Penelitian Edisi Revisi. Jakarta: Trans Info Media.

DIY, D. K. (2017). Profil Kesehatan Provinsi di Yogyakarta. Yogyakarta.

Djanah, N., \& Muslihatun, W. N. (2017). Akupresur terhadap Produksi ASI pada Ibu Post Partum. Jurnal Photon, 8(1), 73-77.

Hardiani, R. (2017). Status Paritas Dan Pekerjaan Ibu Terhadap Pengeluaran ASI Pada Ibu Menyusui 0-6 Bulan. NurseLine Journal, 2.

Kementrian Kesehatan Indonesia. (2018). Data Profil Kesehatan Indonesia. Jakarta.

Lawrence, R., \& Lawrence, R. (2011). Breastfieeding: A Guide For The Medical Profession. Singapore: Elsevier.
Liliana, A., Vidayanti, V., \& Wahyuningsih, M. (2017). Buku Keterampilan Klinis Asuhan Keperawatan Pada Sistem Reproduksi. Yogyakarta: Nuha Medika.

Lismayarsah, M. (2013). Hubungan Tehnik Menyusui Dengan Kelancaran ASI Pada Ibu Menyusui Di Wilayah Kerja Puskesmas Blang Bintang Aceh Besar. STIKES U'Budiyah.

Machmudah, \& Khayati, N. (2014). Produksi ASI Ibu Post Sesarea Dengan Pijat Oketani Dan Oksitosin. Jurnal Ners, 9.

Mansyur, N., \& Dahlan, K. (2014). Buku Ajar Asuhan Kebidanan Masa Nifas. Malang: Selaksa Media.

Mardiyaningsih, E., Setyowati, \& Sabri, L. (2011). Efektifitas Kombinasi Teknik Marmet Dan Pijat Oksitosin Terhadap Produksi ASI Ibu Post Seksio Di Rumah Sakit Wilayah Jawa Tengah. Jurnal Keperawatan Soedirman, 6(1), 31-38.

https://doi.org/http://dx.doi.org/10.2088 4/1.jks.2013.8.2.470

Maritalia, D. (2017). Asuhan Kebidanan Pada Ibu Nifas. https://doi.org/10.1016/03009629(76)90055-4

Marmi. (2015). Asuhan Kebidanan Pada Masa Nifas "Peuperium Care." Yogyakarta: Pustaka Pelajar.

Monika. (2014). Buku Pintar ASI Dan Menyusui. Jakarta: Noura Books.

Notoadmodjo, S. (2014). Metodologi Penelitian Kesehatan. Jakarta: Rineka Cipta. 